\title{
Chewable Soft Capsule Dosage Form
}

National Cancer Institute

\section{Source}

National Cancer Institute. Chewable Soft Capsule Dosage Form. NCI Thesaurus. Code C149368.

A soft tablet that must be chewed to release the active and/or inert ing redient(s). 